SMaLL, R. H. (1984) Practical training in the management of psychiatric combat casualties. Military Medicine, 149, 276-279.

SOLOMON, Z. \& BENBENishTY, R. (1986) The role of proximity, immediacy and expectancy in front-line treatment of combat stress reaction among Israelis in the Lebanon war. American Journal of Psychiatry, 143, 613-617.

SOLOMON, Z., MIKULINCER, M., JAKOB, B. R. (1987) Exposure to recurrent combat stress: combat stress reactions among Israeli soldiers in the 1982 Lebanon war. Psychological Medicine, 17, 433-440.

Sutner, P. B., Bugg, F. \& Allain, A. (1990) Person and situational correlates of post-traumatic stress disorder among POW survivors. Psychological Reports, 66, 912-914.
SUDAK, H. S., CORRADI, R. B., MARTIN, R. S. \& GOLD, F. S. (1984) Antecedent personality factors and the postVietnam syndrome: case reports. Military Medicine, 149, 550-554.

TAYlor, A. J. W. \& Fraser, A. G. (1981) Psychological Sequelae of Operation Overdue following the DC-10 Aircrash in Antarctica. Victoria University of Wellington (N.Z.) Publications in Psychology, No. 27.

Ursano, R. J., Holloway, H. C., Jones, D. R., Rodriguez, A. R. \& Belenky, G. L. (1989) Psychiatric care in the military community; family and military stressors. Hospital and Community Psychiatry, 40, $1284-1289$.

\title{
The psychiatrist and war
}

\author{
Robin Haig, Consultant Psychiatrist, Palliative Care Department, Royal Prince Alfred \\ Hospital, Missenden Road, Camperdown, NSW 2000, Australia, and Senior Lecturer, \\ University of Sydney
}

The year 1991 will be emblazoned on our minds as the year of the Middle East War. Saddam Hussein gave more than a clue to his own psychopathology when he named this conflict "The Mother of All Wars". All nations which actively participate in battle will lose troops and civilians. Physical damage, terror and distress are the immediate accompaniments of battle. Starvation, sub-standard living conditions and infectious disease often follow. Modern weapons and terrorism are capable of inflicting major damage on populations which are far away from the centre of the war.

From the point of view of a psychiatrist who is merely a bystander initially, the major emotional toll of the war is seen months or even years later.

\section{Mental health and war}

The psychological repercussions are prominent and various, ranging from the post-traumatic stress disorders of combatants or passive civilians to a variety of bereavement reactions. Spouses lose partners; children lose fathers; mothers lose sons; troops see comrades being killed. Anticipatory anxiety over potential military attacks takes its own toll.

Curran et al (1990) found that $50 \%$ of survivors of a bomb attack in Enniskillen developed a posttraumatic stress disorder at six months, while all the victims had high scores on the GHQ.

Garb et al (1987) described the bereavement reactions of the soldier in battle. Appropriate grief is not facilitated in the battle or military situation, which may lead to delayed, inappropriate, chronic or excessive grieving, with consequences for subsequent psychological and social functioning. The incidence of psychiatric casualties corresponds directly with the number of men killed or wounded in action.

Wilfred Bion (1986) gave a personal account of his own experiences of chaos and slaughter as the captain of a tank crew in the First World War. Guilt over the death of comrades, anger over the futility of war and the stupidity of authorities left scars which persisted for a life time. It is possible that his subsequent understanding of the basic assumptive groups was strongly influenced by 'commanding' his men in the claustrophobic confines of a tank. 
The youthfulness of widows, loss of children (at any age), untimely death, traumatic death, inability to view the body are all factors associated with an increased risk of more severe or abnormal grieving which may persist for years (Haig, 1990) and are common scenarios in wartime deaths.

The Israelis have conducted several studies on bereavement (many of which involved the death of young men in action) with demonstrable ill effects on widows and children. Auslander (1987) reviewed 19 of these. Physical and emotional problems were common.

It was concluded that among parents bereavement causes problems which do not subside over the course of time, whereas in children, time seemed to heal, albeit slowly. The bereaved who have social ties and utilise them fare better than those who lack social ties.

Inevitably there will be psychological sequelae in individuals who are involved directly or indirectly in a war. Those most profoundly affected, with major implications for their physical and mental health, are those who have sustained losses, particularly those who have been bereaved. The threat of loss, which is most intensive in an active combat zone, may also have some long-term consequences. Psychiatrists who are informed will be in a better position to advise on appropriate intervention, whether it be the strengthening of support networks, psychotherapy, or the use of specific psychiatric treatments. The identification of abnormalities of bereavement and the facilitation of normal grieving is described by Worden (1982) and Haig (1990).

\section{The roots of war}

Prevention is better than cure. Ensuring that future outbreaks do not occur would minimise the above problems. We can speculate on the origins of war, whether it be cultures in collision, economics, territorial intrusion, greed, jealousy, old sores, militaristic traditions, or the projection of stereotypes onto other national groups. There is probably an element of truth in all of these perspectives.

Freud (1957) discussed the roots of war and considered that a primitive lust to kill, the triumph of the victor, the "Law of Talion" and denial of one's own death were all involved. He considered, rather pessimistically, that war could not be abolished, so long as the differences between nations were so great and their mutual repulsion so violent. He proposed that in this situation we should explore our own unconscious attitude to death in order to make life more tolerable.

Examining the roots of aggression is of great importance and involves the sociological, psychological (and developmental) perspectives. The role of loss in the bereft child, the widow or the comrade, leading to a grief which is dominated by anger, followed by recriminative actions against the perceived aggressor, is a circular process which has psychological and sociological components and is observed in many blood feuds and wars between nations.

\section{Conclusions}

The war in the Middle East will be accompanied by an increase in mental health problems in combatants and related civilians, which will continue to emerge after the battles have subsided. Psychiatrists with expertise in post-traumatic stress disorders, problems of maladaptive grieving and related mood disorders will be able to make an important contribution.

Investigating the origins of wars and the roots of aggression in (wo)man is a task which should be given a top priority by all civilised nations. The psychiatrist who has some expertise in considering the intra- and interpersonal origins of aggression in the clinical situation could make important contributions to this task.

It may not be appropriate for a Royal College to adopt a stance in respect to the strategic complexities of a particular war. However, it is of importance in my opinion for bodies such as the Royal College of Psychiatrists to draw the attention of all governments including those of the 'non-aligned' nations (who often supply generous quantities of armaments to both sides in a conflict) to the effects of war on the immediate and long-term functioning of the large number of individuals (and their families) who participate. The prevention of war could be considered to be a public (mental) health measure comparable to the provision of clean water.

\section{References}

AUSLANDER, G. K. (1987) Bereavement research in Israel a critical review of the literature. Israel Journal of Psychiatry and Related Sciences, 24, 33-51.

Bion, W. R. (1986) The Long Weekend 1897-1919. London: Free Association Press.

Curran, P. S., Bell, P., Murray, A., Loughrey, G., RoDdy, R. \& RockE, L. G. (1990) Psychological consequences of the Enniskillen bombing. British Journal of Psychiatry, 156, 479-482.

Freud, S. (1957) Our Attitude Towards Death. Standard edition, vol. XIV, London: Hogarth Press.

GARB, R., Bleich, A. \& LeRER, B. (1987) Bereavement in combat. Psychiatric Clinics of North America, 3, 421436.

HaIG, R. A. (1990) The Anatomy of Grief: Biopsychosocial and Therapeutic Perspectives. Springfield, Illinois: Charles C. Thomas.

WORDEN, J. W. (1982) Grief Counselling and Grief Therapy. New York: Springer. 